\title{
A mechanism of repression of TGFß/ Smad signaling by oncogenic Ras
}

\author{
Marcus Kretzschmar, ${ }^{1,2}$ Jacqueline Doody, ${ }^{1}$ Inna Timokhina, ${ }^{1,2}$ and Joan Massaguée ${ }^{1,3}$ \\ ${ }^{1}$ Cell Biology Program and Howard Hughes Medical Institute, Memorial Sloan-Kettering Cancer Center, \\ New York, New York 10021 USA
}

\begin{abstract}
TGF $\beta$ can override the proliferative effects of EGF and other Ras-activating mitogens in normal epithelial cells. However, epithelial cells harboring oncogenic Ras mutations often show a loss of TGF $\beta$ antimitogenic responses. Here we report that oncogenic Ras inhibits TGF $\beta$ signaling in mammary and lung epithelial cells by negatively regulating the TGF $\beta$ mediators Smad2 and Smad3. Oncogenically activated Ras inhibits the TGF $\beta$-induced nuclear accumulation of Smad2 and Smad3 and Smad-dependent transcription. Ras acting via Erk MAP kinases causes phosphorylation of Smad2 and Smad3 at specific sites in the region linking the DNA-binding domain and the transcriptional activation domain. These sites are separate from the TGF $\beta$ receptor phosphorylation sites that activate Smad nuclear translocation. Mutation of these MAP kinase sites in Smad3 yields a Ras-resistant form that can rescue the growth inhibitory response to TGF $\beta$ in Ras-transformed cells. EGF, which is weaker than oncogenic mutations at activating Ras, induces a less extensive phosphorylation and cytoplasmic retention of Smad2 and Smad3. Our results suggest a mechanism for the counterbalanced regulation of Smad2/Smad3 by TGF $\beta$ and Ras signals in normal cells, and for the silencing of antimitogenic TGF $\beta$ functions by hyperactive Ras in cancer cells.
\end{abstract}

[Key Words: Growth inhibition; MAP kinase; Ras; Smad; TGFß]

Received December 9, 1998; revised version accepted February 10, 1999.

The cytokine TGF $\beta$ plays a dual role in tumorigenesis. On one hand, TGF $\beta$ inhibits the proliferation of normal epithelial, endothelial, and hematopoietic cells, thus being crucial for the homeostasis of these tissues (Massagué 1990; Roberts and Sporn 1993; Alexandrow and Moses 1995). TGF $\beta$ signaling is lost in some cancers by mutational inactivation of TGF $\beta$ signal-transduction components. A substantial proportion of colorectal or pancreatic cancers harbor inactivating mutations in the genes encoding the TGF $\beta$ type II receptor (T $\beta \mathrm{R}-\mathrm{II})$ or its mediators, Smad2 and Smad4 (Markowitz et al. 1995; Eppert et al. 1996; Hahn et al. 1996; Heldin et al. 1997; Chen et al. 1998; Goggins et al. 1998; Massagué 1998; Grady et al. 1999). In the mouse, expression of a dominant-negative $T \beta R-I I$ transgene in the pancreas, mammary gland, or skin causes abnormal growth of these tissues (Böttinger et al. 1996; Wang et al. 1997; Gorska et al. 1998). Furthermore, Smad3 mutant mice (Zhu et al. 1998) or the combined loss of wild-type Smad4 and APC alleles in compound heterozygotes (Takaku et al. 1998) lead to formation of invasive intestinal tumors.

On the other hand, TGF $\beta$ can exacerbate the malignant phenotype at later stages of tumorigenesis /Cui et al. 1996; Barrack 1997; Factor et al. 1997; Reiss and Bar-

\footnotetext{
${ }^{2}$ Present address: Ruttenberg Cancer Center, Mount Sinai School of Medicine, New York, New York 10029 USA.

${ }^{3}$ Corresponding author.

E-MAIL j-massague@ski.mskcc.org; FAX (212) 717-3298.
}

cellos-Hoff 1997). TGF $\beta$ is abundantly expressed in various tumors of epithelial origin (Derynck et al. 1985; Keski-Oja et al. 1987) in which it can suppress immune surveillance (Letterio and Roberts 1998), foster tumor invasion (Cui et al. 1996), and promote the development of metastases (Welch et al. 1990; Yin et al. 1999). These effects become manifest in tumor cells that retain TGF $\beta$ receptors but have lost the capacity to respond to TGF $\beta$ with growth arrest. Such a state of altered TGF $\beta$ responsiveness is observed in Ras-transformed cells. These cells typically exhibit a limited growth inhibitory response to TGFß (Schwarz et al. 1988; Houck et al. 1989; Valverius et al. 1989; Longstreet et al. 1992; Filmus and Kerbel 1993) but may respond to TGF $\beta$ with invasive activity (Oft et al. 1996) and metastatic behavior (Oft et al. 1998; Yin et al. 1999).

TGF $\beta$ exerts growth inhibitory and transcriptional responses through Smad2 and the highly related protein Smad3, which are direct TGF $\beta$ receptor substrates, whereas Smad1 is a substrate and mediator of bone morphogenetic protein (BMP) receptors (Heldin et al. 1997; Massagué 1998). Receptor-mediated phosphorylation of these Smads, which occurs at serine residues in the carboxy-terminal SSXS sequence (Macias-Silva et al. 1996; Kretzschmar et al. 1997b), induces their association with the shared partner Smad4 followed by translocation into the nucleus in which these complexes activate transcription of specific genes (Heldin et al. 1997; Massagué 1998). Smad proteins contain a conserved amino-termi- 
nal domain that binds DNA (Shi et al. 1998), and a conserved carboxy-terminal domain that binds receptors, partner Smads, and transcription coactivators (Shi et al. 1997; X. Chen et al. 1998). These two domains are separated by a more divergent linker region.

How oncogenic Ras counteracts the growth inhibitory effects of TGF $\beta$ has remained unknown. Although oncogenic Ras can prevent the antimitogenic effects of TGF $\beta$, TGF $\beta$ potently overcomes the mitogenic effects of Rasactivating factors such as EGF in epithelial cells (Massagué 1990; Roberts and Sporn 1993; Alexandrow and Moses 1995). To investigate the molecular basis for these interactions, we focused on $\operatorname{Smad} 2$ and Smad3 as possible targets of inhibition by Ras. Here we show that Ras activation by oncogenic mutations or, to a lesser extent, by EGF receptor signals, inhibits the TGF 3 -induced nuclear accumulation of Smad2 and Smad3. These effects are mediated by phosphorylation of specific sites in Smad2 and Smad3, and we demonstrate that these sites are distinct from the TGF $\beta$ receptor phosphorylation sites. We present evidence that this mechanism mediates the silencing of TGF $\beta$ antimitogenic responses in Ras-transformed cells, whereas in normal cells this mechanism serves to adjust the level of TGF $\beta /$ Smad signaling according to the level of Ras activity in the cell. These results reconcile a diverse body of observations on the interaction between the TGF $\beta$ and Ras pathways, and provide insights into the subversion of TGF $\beta$ signaling by oncogenic Ras mutations in cancer.

\section{Results}

\section{Ras inhibition of Smad-dependent TGF $\beta$ responses}

We investigated Ras as an antagonist of TGF $\beta$ signaling using a well-characterized mouse mammary epithelial cell system (Oft et al. 1996). The parental cell line EpH4 is nontumorigenic and responds to TGF $\beta$ with growth inhibition, whereas its v-Ha-Ras-transformed derivative,
EpRas, responds with a transition into a fibroblastoid phenotype that is not growth inhibited and is highly invasive in vivo (Oft et al. 1996). We investigated whether loss of growth inhibitory responses to TGF $\beta$ in EpRas cells might be related to Ras inhibition of Smad transcriptional functions. One of the best understood Smad target promoters is that of the Mix.2 gene from Xenopus laevis (Y. Chen et al. 1996; X. Chen et al. 1997; Liu et al. 1997). On translocation into the nucleus, receptor-activated Smad2 or Smad3 associate with the DNA-binding protein FAST1 to form a transcriptional complex on the activin/TGF $\beta$ response element (ARE) of the Mix.2 promoter (Y. Chen et al. 1996; X. Chen et al. 1997; Liu et al. 1997). Strong (up to 14-fold) activation of an ARE reporter construct (A3-Luc) by TGF $\beta$ was achieved in EpH4 cells cotransfected with FAST1 (data not shown) or its mammalian homolog FAST2 (Labbé et al. 1998; Zhou et al. 1998; Liu et al. 1999) (Fig. 1A). In contrast, FAST2transfected EpRas cells showed only a weak (twofold) activation of A3-Luc by TGF $\beta$, suggesting that Smad signaling was impaired (Fig. 1A).

EpRas cells may have accumulated Ras-independent defects in TGF $\beta$ signaling over time. Therefore, we verified the ability of oncogenic Ras to inhibit A3-Luc activation by transiently transfecting a $\mathrm{H}-\mathrm{Ras}^{\mathrm{V} 12}$ oncogene into $\mathrm{Mvl}$ Lu mink lung epithelial cells. This cell line is highly sensitive to growth inhibition and A3-Luc activation by TGF $\beta$. The TGF $\beta$-induced activation of A3Luc in these cells was strongly inhibited by cotransfection of H-Ras ${ }^{\mathrm{V} 12}$ (Fig. 1B). Transient transfection of $\mathrm{H}-\mathrm{Ras}^{\mathrm{V} 12}$ also inhibited the antiproliferative response to TGF $\beta$, as determined with an E2F-1 reporter construct whose activity is a measure of $\mathrm{G}_{1}$ progression (Lukas et al. 1997; Fig. 1C). Thus, in a stably transfected mammary epithelial cell line and in a transiently transfected lung epithelial cell line, the presence of oncogenic Ras caused not only a loss of antiproliferative responses to TGF $\beta$ but also of Smad-dependent transcriptional responses.
A

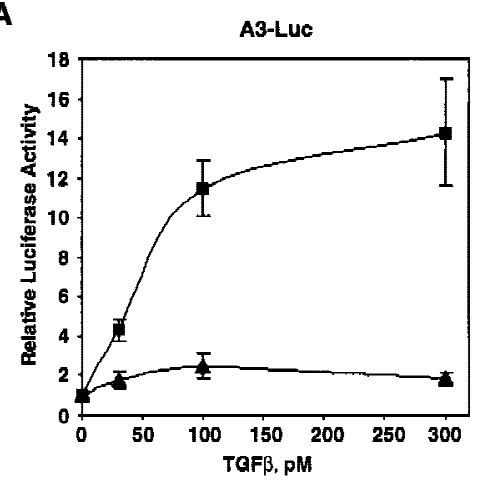

B

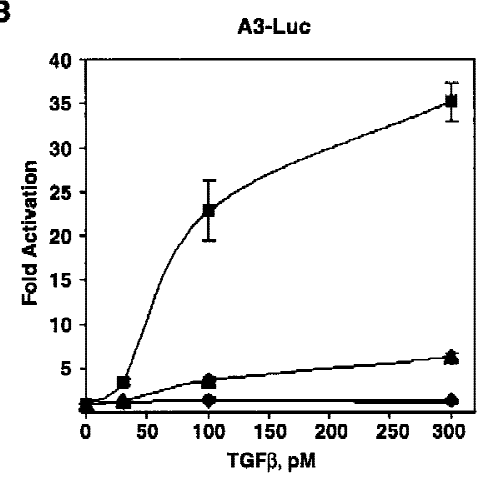

C

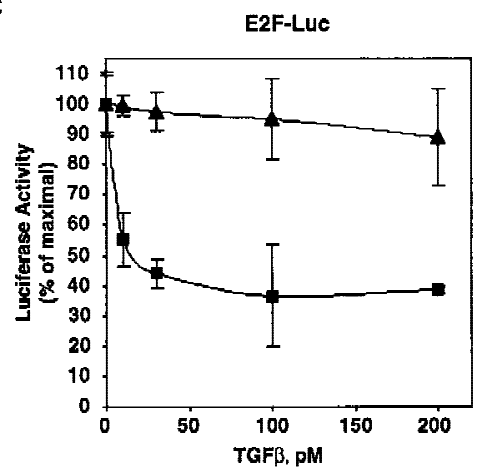

Figure 1. Oncogenic H-Ras inhibits Smad-dependent TGF $\beta$ transcriptional responses. (A) Activation of the A3-Luciferase reporter construct by the indicated concentrations of TGF $\beta$ was analyzed in EpH4 and EpRas mammary epithelial cells. (口) EpH4; ( $\mathbf{\Delta})$ EpRas. (B) TGF $\beta$ - and FAST2-dependent activation of the A3-Luc reporter in Mv1Lu mink lung epithelial cells transfected with or without

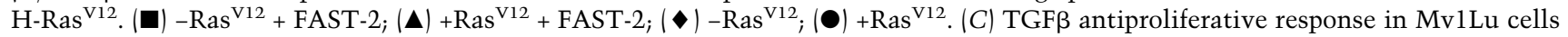
transfected with or without $\mathrm{H}-\mathrm{Ras}^{\mathrm{V} 12}$. ( $\left.\mathbf{\square}\right)-\operatorname{Ras}^{\mathrm{V} 12} ;(\mathbf{\Delta})+\operatorname{Ras}^{\mathrm{V} 12} . \mathrm{G}_{1}$ progression activity was determined with an E2F reporter construct driving luciferase expression. In all cases, data are the average of triplicates \pm S.D. 


\section{Inhibition of Smad2/Smad3 nuclear accumulation by oncogenic Ras}

Translocation of Smad2 and Smad3 into the nucleus on receptor-mediated phosphorylation is a central event in TGF $\beta$ signal transduction (Heldin et al. 1997; Massagué 1998). Growth factors that signal via Ras, such as EGF, can inhibit the BMP-induced nuclear accumulation of Smad1 by inducing its phosphorylation at four PXSP Erk sites (Kretzschmar et al. 1997a). These four sites are not conserved in Smad2 or Smad3. Nevertheless, we decided to investigate whether oncogenic Ras might inhibit nuclear accumulation of endogenous Smads in response to TGFß. Rabbit polyclonal antibodies were raised against the recombinant linker region of Smad2 and tested by Western immunoblotting on transfected COS cells expressing different Flag-tagged Smads. These antibodies specifically recognized Smad2, and to a lesser extent Smad3, but not Smad1 or Smad4 (Fig. 2A). This cross-reactivity profile is consistent with the high level of amino acid sequence similarity of the $\operatorname{Smad} 2$ and Smad3 linker region and the extensive divergence of this region in the other Smads (Zhang et al. 1996). Immunoblot assays of untransfected EpH4, EpRas, and Mv1Lu cells with these antibodies demonstrated the presence of Smad2 and lower levels of Smad3 in each cell line (Fig. 2B). Using antibodies that specifically recognize the TGF $\beta$ receptor-phosphorylated Smad2, we determined that endogenous Smad2 in both EpH4 and EpRas cells is phosphorylated in response to TGF (Fig. 2C). Thus, Ras transformation did not interfere with TGF $\beta$ receptor-mediated phosphorylation of Smad2 in EpRas cells.

We determined the immunofluorescence pattern of endogenous proteins in EpH4 and EpRas using antiSmad2/Smad3 antibodies (Fig. 2D). In the absence of TGF 3 , both cell lines showed anti-Smad2/Smad3 staining throughout the cell. On TGF $\beta$ addition, $>95 \%$ of the EpH4 cells showed an accumulation of all the Smad2/ Smad3 immunostaining in the nucleus (Fig. 2D). This nuclear accumulation was rapid and lasted for at least 3 hr (Fig. 2E). Compared to EpH4 cells, EpRas cells responded to TGF $\beta$ with a limited accumulation of Smad2/Smad3 in the nucleus. Furthermore, this accumulation was slow and only partial, as most cells with predominant nuclear staining still showed an extensive staining in the cytoplasm (Fig. 2D,E). We also examined the pattern of $\mathrm{Smad} 2 / \mathrm{Smad} 3$ nuclear accumulation in five human colon carcinoma cell lines, three of which contain oncogenic K-Ras mutations (Table 1). Nuclear accumulation of $\mathrm{Smad} 2 / \mathrm{Smad} 3$ in response to an intermediate (10 pM) TGF $\beta$ concentration was poor or absent in these three cell lines but extensive in the two cell lines containing wild-type ras alleles.

To directly test whether oncogenic Ras can interfere with nuclear accumulation of endogenous Smad2 and Smad3, we transiently transfected Mv1Lu cells with H$\operatorname{Ras}^{\mathrm{V} 12}$. Cotransfection of the green fluorescence protein (GFP) served to distinguish transfected from nontrans-
Figure 2. TGF $\beta$-induced nuclear accumulation of Smad2 and Smad3 in EpH4 and EpRas cells. $(A)$ COS cells transfected with Flag-tagged versions of Smad1, Smad2, Smad3, or Smad4 were subjected to Western immunoblotting with antiFlag antibodies as a positive control, or antibodies raised against the linker region of Smad2. (B) Untransfected EpH4, EpRas, and $\mathrm{Mv} 1 \mathrm{Lu}$ cell extracts were subjected to Western immunoblotting with affinitypurified anti-Smad2/Smad3 (top) or nonimmune serum (bottom). (Asterisks) Nonspecific bands. $(C)$ EpRas and EpH4 cells were stimulated with TGF $\beta$ for $30 \mathrm{~min}$. Cell lysates were subjected to Western immunoblotting with either antibodies against receptor-phosphorylated Smad2 (top) or anti-Smad2/Smad3 antibodies (bottom). (D) In a similar experiment, endogenous Smad2 and Smad3 were visualized by anti-Smad2/Smad3 immunofluorescence. $(E) \mathrm{EpH} 4(\boldsymbol{\square})$ and EpRas $(\boldsymbol{\Delta})$ cells were treated with TGF $\beta$ for different time periods. Following immunofluorescence staining, the percentage of cells with Smad2/Smad3 staining predominantly or exclusively in the nucleus was determined.

\section{A}

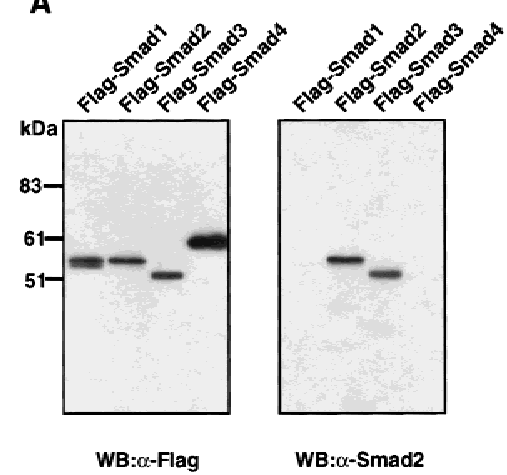

B

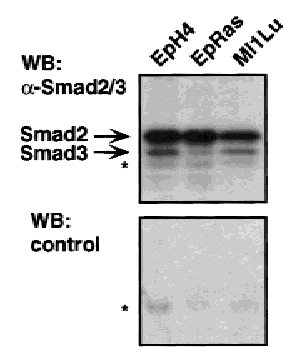

D
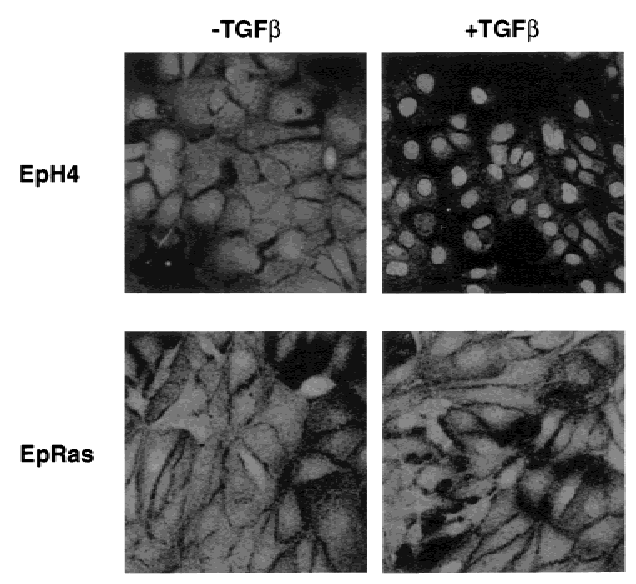

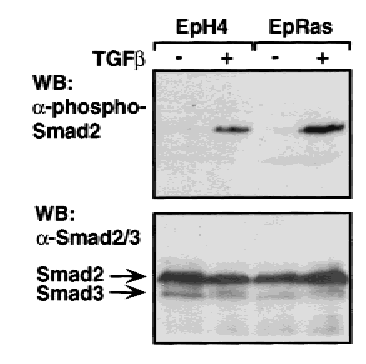

C

E

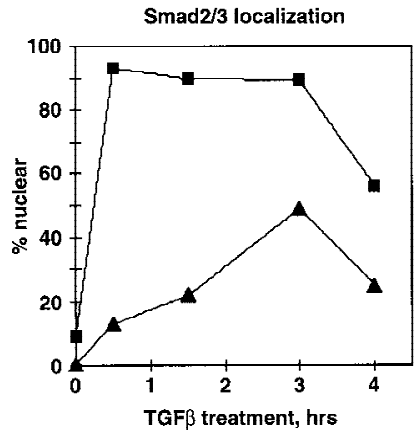


Table 1. TGFß-induced nuclear accumulation of Smad2/3 in human colon cancer cell lines

\begin{tabular}{|c|c|c|c|c|c|}
\hline \multirow[b]{2}{*}{ Cell line } & \multirow[b]{2}{*}{ ras allele ${ }^{\mathrm{a}}$} & \multirow[b]{2}{*}{ Other alterations ${ }^{\mathrm{a}}$} & \multicolumn{3}{|c|}{ Smad2/Smad 3, \% nuclear ${ }^{b}$} \\
\hline & & & nontransfected & vector & $\mathrm{H}-\mathrm{Ras}^{\mathrm{V} 12}$ \\
\hline HT-29 & wild type & $p 53^{-} / A P C^{-} / s r c$ & 93 & 75 & 12 \\
\hline Colo205 & wild type & $p 53^{-} / A P C^{-} / 1 c k / s r c / m y b$ & 45 & 48 & 4 \\
\hline SW620 & $\mathrm{K}-\operatorname{ras}^{\mathrm{V} 12}$ & $p 53^{-} / A P C^{-} / s r c / m y b$ & 10 & N.T. & N.T. \\
\hline LoVo & $\mathrm{K}-$ ras $^{\mathrm{D} 12}$ & $p 53^{-} / A P C^{-} / s r c$ & $<2$ & N.T. & N.T. \\
\hline DLD-1 & $\mathrm{K}-$ ras $^{\mathrm{D} 13}$ & $p 53^{-} / A P C^{-}$ & $<2$ & N.T. & N.T. \\
\hline
\end{tabular}

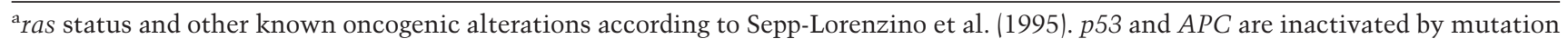
or not expressed. The oncogenes listed are mutated or overexpressed.

${ }^{\mathrm{b} C e l l s}$ were either not transfected, transfected with GFP vector and empty vector (vector), or GFP vector and H-Ras ${ }^{\mathrm{V} 12}$ vector $\left(\mathrm{H}-\mathrm{Ras}^{\mathrm{V} 12}\right)$. Cells were incubated with 10 pM TGF $\beta$ for $30 \mathrm{~min}$ and subjected to anti-Smad2/3 immunofluorescence. The percentage of cells with predominant nuclear staining in the total nontransfected population or in the transfected (GFP positive) population is shown. (N.T.) Not tested.

fected cells in the dish. Up to $95 \%$ of the control vector transfected (GFP positive) cells showed nuclear accumulation of endogenous Smad2/Smad3 in response to TGF $\beta$ (Fig. 3A). In contrast, only a small proportion (16\%) of the H-Ras ${ }^{\mathrm{V} 12}$ transfected cells showed nuclear accumulation of Smad2/Smad3 (Fig. 3A). A similar effect was observed in cells expressing a constitutively active form of Mek1 (Fig. 3B), which is an activator of Erk MAP kinases downstream of Ras (Davis 1993). GFP-negative cells, which served as internal controls in these assays, had extensive Smad2/Smad3 staining in the nucleus in the presence of TGF $\beta$ (Fig. 3). A similar inhibition of Smad2/Smad3 nuclear accumulation by transfection of a $\mathrm{H}-\mathrm{Ras}^{\mathrm{V} 12}$ vector was observed in the two tumor cell lines containing wild-type ras alleles (Table 1).

Ras induces phosphorylation of Smad2 and Smad3 in the linker region

Next, we investigated whether Ras inhibition of Smad nuclear accumulation involves Smad phosphorylation. Activated Ras propagates signals through the activation of protein kinases including the MAP kinases $p 44^{\text {Erk1 }}$ and $\mathrm{p} 42^{\mathrm{Erk2}}$ (Davis 1993). The levels of these two proteins were similar in EpH4 and EpRas cells, as determined by Western immunoblotting with anti-Erk antibodies (Fig. 4A, bottom). However, the level of Erk activity was higher in EpRas cells than in EpH4 cells, as determined by measuring the kinase activity of Erk immunoprecipitates (Fig. 4A, top). This result was consistent with the presence of hyperactive Ras in EpRas cells. Interestingly, immunoprecipitation of endogenous Smad 2 and Smad 3 from ${ }^{32}$ P-labeled cells showed that the level of phosphorylation of these proteins was higher in EpRas cells than in EpH4 cells (Fig. 4B). Elution of the ${ }^{32}$ P-labeled EpRas Smad band from these gels followed by digestion with trypsin yielded labeled products of no less than $13 \mathrm{kD}$, whereas digestion with $\alpha$-chymotrypsin yielded mostly products of $<5 \mathrm{kD}$ (data not shown). On the basis of the predicted proteolytic sites of Smad2 and Smad3 (Zhang et al. 1996), the observed digestion pattern suggests that most of the phosphorylation resides in the linker region of these proteins.
Cell stimulation with EGF has been shown to inhibit the BMP-induced nuclear accumulation of Smad1, and this effect requires the phosphorylation of four Erk kinase sites (PXS/TP) in the linker region of Smad1 (Kretzschmar et al. 1997a). Smad2 has only one Erk site in the linker region (Thr-220) and Smad3 has two (Thr178, Ser-212) (Fig. 5A). However, the Smad2 linker region has three Ser-Pro sequences (Ser-245, Ser-250, Ser-255) and Smad3 has two (Ser-203, Ser-207). These sequences can serve as phosphorylation sites for proline-directed protein kinases including Erk (Davis 1993). Therefore, we asked whether Ras pathway activation causes phosphorylation of these sites. Smad2 and Smad3 constructs were generated that encoded serine-to-alanine or threonine-to-valine mutations at all these sites (Erk/Pro-directed kinase site mutant constructs, EPSM). Wild-type or EPSM Smad constructs containing a amino-terminal Flag epitope were transiently transfected either alone or together with $\mathrm{H}-\mathrm{Ras}^{\mathrm{V} 12}$ or activated Mek1 vectors into Mv1Lu/R1B-L17 cells. Cell labeling with ${ }^{32} \mathrm{P}$ followed by anti-Flag immunoprecipitation showed that Smad2 and Smad3 were phosphorylated under normal culture conditions, and the phosphorylation level of these proteins was increased by transfection of $\mathrm{H}-\mathrm{Ras}^{\mathrm{V} 12}$ or activated Mek1 vectors (Fig. 5B,C). Treatment of the Rastransfected cells with the inhibitor of Mek1 activation PD98059 (Alessi et al. 1995) or the inhibitor of phosphatidylinositol 3-kinase, Wortmannin (Ui et al. 1995), partially inhibited Smad2 and Smad3 phosphorylation, implicating these kinases in the Ras-induced phosphorylation (Fig. 5B,C). The results suggest that the basal activity of the Ras pathway and, to a larger extent, the hyperactivation of this pathway by H-Ras ${ }^{\mathrm{V} 12}$ or activated Mek1, cause the phosphorylation of Smad2 and Smad3.

\section{Erk kinase phosphorylation sites in the linker region}

Compared with the transfected Smad2 and Smad3, their corresponding EPSM constructs showed very low levels of phosphorylation, and these levels were not increased by $\mathrm{H}-\mathrm{Ras}^{\mathrm{V} 12}$ (Fig. 5B,C). To verify that Erk kinases can directly phosphorylate Smad2 and Smad3 at the identified sites, we performed in vitro kinase assays using re- 
A
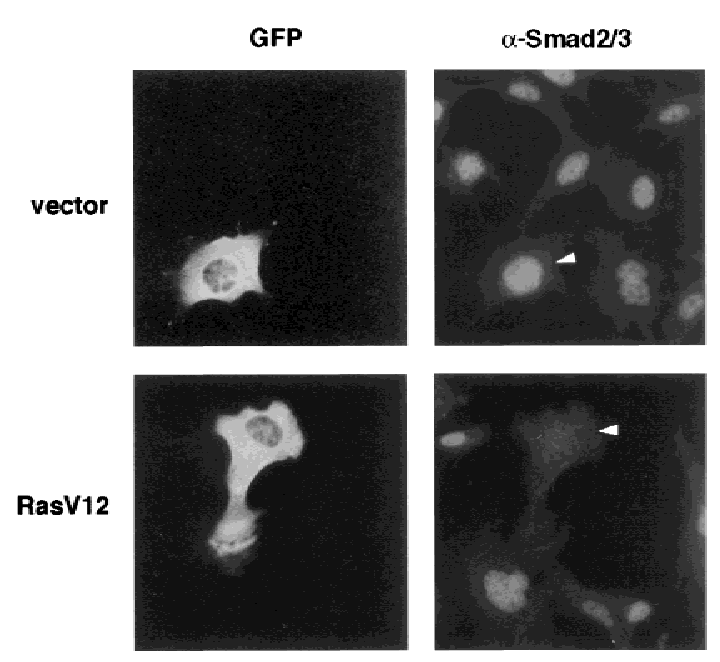

B

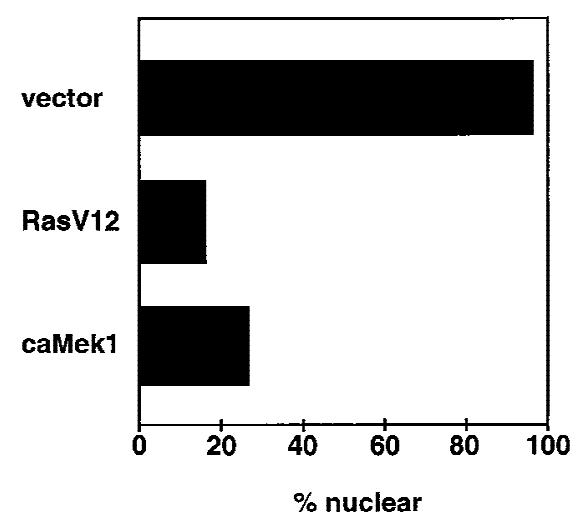

Figure 3. Nuclear accumulation of Smads in response to TGF $\beta$ is inhibited by oncogenic $\mathrm{H}-\mathrm{Ras}^{\mathrm{V} 12}$ or constitutively active Mek1. Mv1Lu cells were transiently transfected with empty vector, H-Ras ${ }^{\mathrm{V} 12}$ or constitutively active Mek1 (ca Mek1), and then treated with TGF $\beta$ for $30 \mathrm{~min}$ before fixation. Transfected cells were marked by cotransfection with GFP. Endogenous proteins were visualized by anti-Smad2/Smad3 immunofluorescence by a rhodamine-coupled system. (Arrowheads) GFP-positive cells. (A) Representative micrographs of the control and $\mathrm{H}-\mathrm{Ras}^{\mathrm{V} 12}$ transfectants visualizing the GFP and anti-Smad2/ Smad3 signals. (B) Percentage of GFP-positive cells with Smad2/Smad3 predominantly in the nucleus under the three experimental conditions.

combinant forms of these proteins. Recombinant, activated Erk2 phosphorylated Smad2 and Smad3 to a much greater extent than it phosphorylated Smad2-EPSM or Smad3-EPSM (Fig. 5D). We also tested Smad2 and Smad3 constructs containing hydroxyl residue mutations either in the PXS/TP sites or in the other SP sites. Each of these four mutants showed a partial loss of phosphorylation compared with the EPSM constructs, both in Ras transfected cells and in in vitro Erk2 phosphorylation assays (data not shown).
We also tested Smad2(3SA) and Smad3(3SA) constructs that contain alanine mutations in the three serines of the carboxy-terminal sequence SSXS (Kretzschmar et al. 1997b). These serines serve as TGF $\beta$ receptor phosphorylation sites and are required for Smad translocation into the nucleus (Macias-Silva et al. 1996). $\mathrm{H}-\mathrm{Ras}^{\mathrm{V} 12}$ transfection of Mv1Lu/R1B-L17 cells induced phosphorylation of both 3SA constructs (Fig. 5E), arguing that the TGF $\beta$-receptor phosphorylation sites are not required for Ras-induced phosphorylation. Collectively, these results suggest that oncogenic Ras, acting through Mek1 and Erk kinases, induces the phosphorylation of Smad2 and Smad3 at a cluster of Ser/Thr-Pro sites in the linker region.

Effects of EGF on Smad2 and Smad3 phosphorylation and nuclear accumulation

As EGF is a physiological activator of the Ras pathway (Vojtek and Der 1998), we investigated its effects on Smad2 and Smad3 phosphorylation and nuclear accumulation. EGF was reported to cause an increase in the phosphorylation levels of an endogenous Smad2 in Mv1Lu cells (deCaesteker et al. 1998). In agreement with this result, we observed that EGF induces phosphorylation of exogenous Smad2 and Smad3 in transfected Mv1Lu/R1B-L17 cells (Fig. 6A). However, Ras activation in response to EGF is thought to be less extensive than Ras activation by oncogenic mutations. The increase in
A

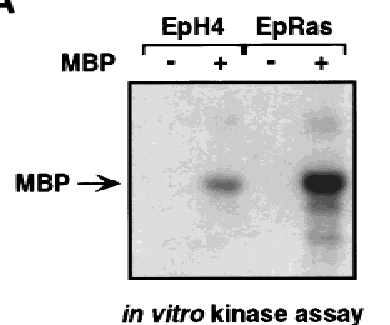

EpH4 EpRas

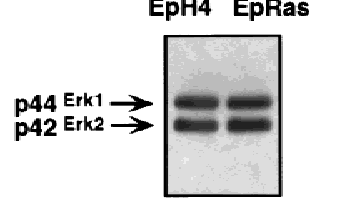

WB: $\alpha$-Erk
B

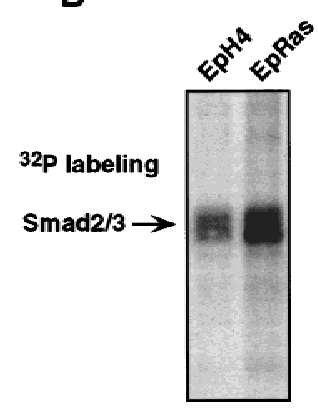

WB: $\alpha-S \operatorname{mad} 2 / 3$

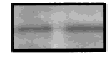

Figure 4. Elevated Erk activity and Smad2/Smad3 phosphorylation levels in EpRas cells. (A) The kinase activity associated with anti-Erk immunoprecipitates from EpH4 and EpRas cells was determined with myelin basic protein $(\mathrm{MBP})$ as a substrate. The relative levels of Erk1 and Erk2 were determined by antiErk Western immunoblotting. $(B)$ The phosphorylation level of Smad2 and Smad3 in EpH4 and EpRas cells was determined by immunoprecipitation from ${ }^{32} \mathrm{P}$-labeled cells. The relative levels of Smads were determined by anti-Smad2/Smad3 Western immunoblotting of unlabeled cell extracts prepared in parallel. 
A

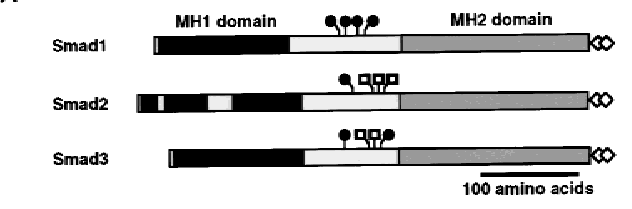

B

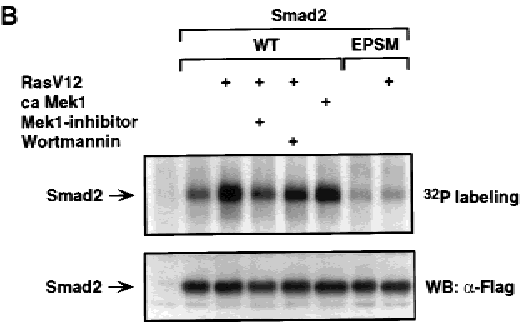

C

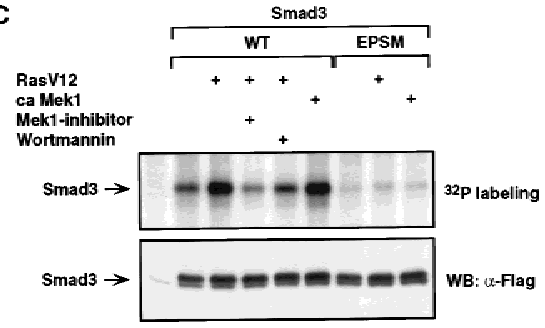

D

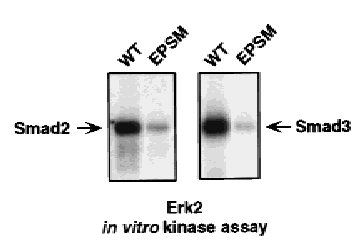

$\mathbf{E}$

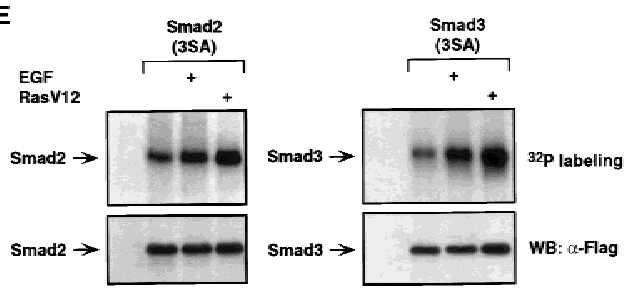

Figure 5. Oncogenic H-Ras ${ }^{\mathrm{V} 12}$ causes phosphorylation of Smad2 and Smad3 through Mek1 at Ser/Thr-Pro sites in the linker region. (A) Schematic representation of phosphorylation sites in the region that links the DNA binding domain (MH1 domain) and the receptor-interaction/transcriptional domain (MH2 domain) in Smad1, Smad2, and Smad3. (-) Erk consensus sites (PXS/TP); ( $\square$ ) serine/proline motifs, which may serve as phosphorylation sites for proline-directed kinases; $(\diamond)$ receptor phosphorylation sites. $(B, C)$ Vectors encoding Flag-tagged wildtype (WT) Smads or mutant Smads lacking all four potential phosphorylation sites in the linker region (EPSM constructs), were used. These constructs were cotransfected with vectors encoding $\mathrm{H}-\mathrm{Ras}^{\mathrm{V} 12}$ or constitutively active Mek1 into Mv1Lu/R1B-L17 cells as indicated. The phosphorylation level of transfected Smads was determined by anti-Flag immunoprecipitation from ${ }^{32} \mathrm{P}$ labeled cells. PD98058 (a Mek1 inhibitor) or wortmannin (a phosphatidyl inositol 3'-kinase inhibitor) were added $1.5 \mathrm{hr}$ prior to cell lysis, as indicated. Smad expression was monitored by anti-Flag immunoblotting of cell lysates. (D) Purified, recombinant Smad proteins (wild-type or EPSM mutants) were tested as substrates for recombinant activated Erk2 in in vitro kinase assays. Identical amounts of recombinant Smad protein was added to all assays. (E) Effects of H-Ras ${ }^{\mathrm{V} 12}$ cotransfection or EGF addition (18 nM, $30 \mathrm{~min}$ ) on the phosphorylation of Flag-tagged Smad constructs containing Ser $\rightarrow$ Ala mutation in the carboxy-terminal SSXS receptor phosphorylation sites. Other assay conditions and controls were as described above.

Smad2 or Smad3 phosphorylation induced by EGF in $\mathrm{Mv} 1 \mathrm{Lu}$ cells was more limited than that induced by $\mathrm{H}$ $\mathrm{Ras}^{\mathrm{V} 12}$. The EGF-induced phosphorylation requires the same cluster of sites in the linker region, as EGF did not elevate the phosphorylation of Smad2-EPSM or Smad3EPSM, which lack these sites (Fig. 6A). Like H-Ras ${ }^{\mathrm{v} 12}$, EGF elevated the phosphorylation of Smad2(3SA) and Smad3(3SA), which lack the TGF $\beta$ receptor phosphorylation sites (Fig. 5E).

Next, we examined the effect of EGF on TGF $\beta$-induced nuclear accumulation of endogenous Smads. EGF added alone had no discernible effect on the staining pattern of endogenous Smad2/Smad3 in Mv1Lu cells. Whether added alone or together with EGF, TGF $\beta$ induced an accumulation of Smad2/Smad3 in the nucleus (Fig. 6B). However, EGF clearly limited the extent of this accumulation. When TGF $\beta$ was added alone, almost all cells in the population showed an intense nuclear accumulation of Smad2/Smad3 with very little immunostaining left in the cytoplasm. In the presence of EGF, the nuclear accumulation of Smad2/Smad3 was less extensive, and a substantial level of Smad2/Smad3 staining remained in the cytoplasm in most cells (Fig. 6B). EGF was more effective at inhibiting the effect of $10 \mathrm{pm}$ TGF $\beta$ (Fig. 6B) than that of 100 pM TGF $\beta$ (data not shown), suggesting that the extent of Smad2/Smad3 nuclear accumulation depends on the relative strength of countervailing TGF $\beta$ and EGF signals.

\section{Linker phosphorylation inhibits nuclear accumulation}

These results showed a correlation between a Ras-induced phosphorylation of a cluster of MAP kinase sites in the linker region of Smad2/Smad3 and an inhibition of TGFß-induced nuclear accumulation of these Smads. To directly test whether phosphorylation of these sites is required for inhibition of nuclear accumulation, we cotransfected vectors encoding activated Mek1 and either Flag-tagged Smad3 or Smad3-EPSM constructs into Mv1Lu cells. Similar to its effect on the nuclear accumulation of endogenous Smad2/Smad3 (see Fig. 3), the activated Mek1 inhibited the TGF $\beta$-induced nuclear accumulation of Flag-Smad3 (Fig. 7A,B). However, FlagSmad3-EPSM was resistant to this inhibitory effect, as it accumulated in the nucleus in response to TGF $\beta$ even in the presence of activated Mek1 (Fig. 7A,B). Inhibition of Smad3 nuclear accumulation by activated Mek1 therefore requires the linker region MAP kinase phosphorylation sites.

\section{Ras-resistant Smad3 rescues TGF $\beta$ antimitogenic and transcriptional responses}

Finally, we used the Smad3-EPSM construct to investigate whether the TGF $\beta$ responses lost in EpRas cells could be restored by a Ras-resistant Smad3 mutant. TGF $\beta$ addition inhibited the activity of the E2F-1-lucif- 
A

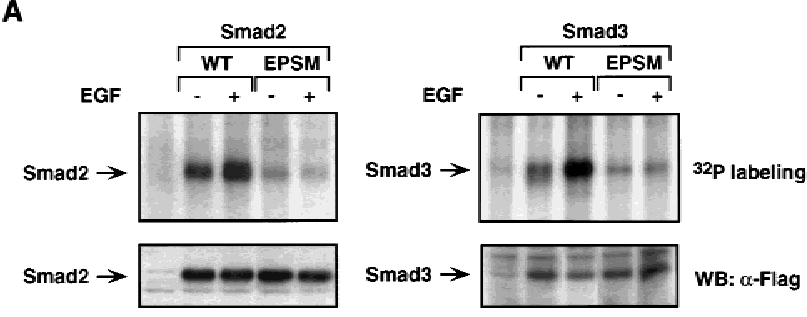

B
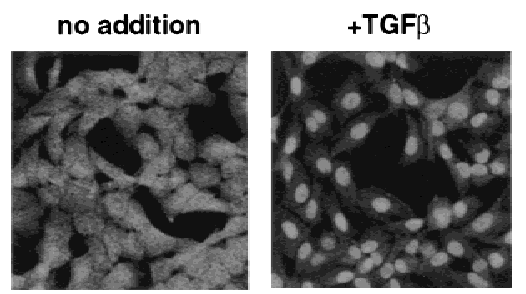

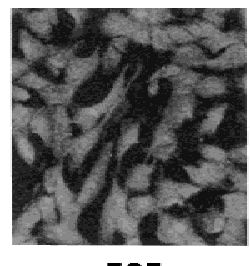

+EGF

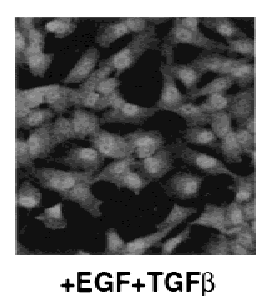

Figure 6. EGF induces phosphorylation and inhibits TGF $\beta$-dependent nuclear accumulation of $\operatorname{Smad} 2$ and $\operatorname{Smad} 3$. $(A)$ Mv1Lu/R1B-L17 cells transfected with vectors encoding the indicated Flag-tagged Smad constructs were labeled with ${ }^{32} \mathrm{P}$, and incubated with EGF for $30 \mathrm{~min}$. The phosphorylation level of the transfected Smads was determined by anti-Flag immunoprecipitation. Smad expression was controlled by anti-Flag immunoblotting of cell lysates. (B) Mv1Lu cells were incubated with EGF for $60 \mathrm{~min}$ before fixation (bottom) and/or TGF $\beta$ for $30 \mathrm{~min}$ before fixation (right), and endogenous $\operatorname{Smad} 2 / 3$ visualized by immunofluorescence. Note the lack of cytoplasmic staining in cells treated with TGF $\beta$ alone, and the cytoplasmic staining remaining in cells treated with TGF $\beta$ plus EGF.

erase reporter assay in EpH4 cells but not in EpRas cells (Fig. 8). This result is consistent with the previously described loss of antiproliferative responses in EpRas cells (Oft et al. 1997). Transfection of either wild-type Smad3 or Smad3-EPSM into EpH4 cells did not significantly enhance this antimitogenic effect of TGF $\beta$ (Fig. 8A). However, Smad3-EPSM restored the ability of TGF $\beta$ to inhibit the E2F-1 reporter in EpRas cells, whereas wildtype Smad3 had only a small effect (Fig. 8A).

We also tested the effect of Smad3 or Smad3-EPSM transfection on the activation of the A3-Luc reporter (Fig. 8B). A3-Luc activation by TGF $\beta$ in EpH4 cells was only slightly increased by transfection of Smad3 or Smad3-EPSM vectors. However, transfection of Smad3EPSM into EpRas cells strongly enhanced the otherwise limited response of A3-Luc to TGF $\beta$, whereas transfection of the wild-type Smad3 had only a small effect (Fig. 8B). EpRas cells transfected with Smad3-EPSM vector had a high level of basal luciferase activity that may be due to spontaneous accumulation of the overexpressed product in the nucleus. These results further suggest that Smad phosphorylation by Ras-activated MAP kinases is responsible for the decreased responsiveness of Ras-transformed cells to TGF $\beta$.

\section{Discussion}

We have investigated the mechanism of inhibition of TGF $\beta$ signaling by the Ras pathway in epithelial cells. Our results suggest that Ras activation induces the phosphorylation of MAP kinase sites in the linker region of Smad2 and Smad3, inhibiting the nuclear accumulation of the Smads and their ability to mediate TGF $\beta$ antiproliferative responses and other effects. In normal epithelial cells, this mechanism may function to adjust the level of Smad signaling according to the level of Ras activity. However, in the case of Ras hyperactivation by oncogenic mutations, a common event in several human cancers, the same mechanism may cause the loss of growth inhibition by TGF $\beta$.

\section{Repression of TGF $\beta /$ Smad signaling by the Ras pathway}

Numerous reports have described a correlation between Ras transformation and deficient TGF $\beta$ responsiveness, particularly with regards to TGF $\beta$ antimitogenic responses. Ras transformation of lung, intestinal, liver, or mammary epithelial cells confers resistance to growth inhibition by TGFß (Schwarz et al. 1988; Houck et al. 1989; Valverius et al. 1989; Longstreet et al. 1992; Filmus and Kerbel 1993). Microinjection of oncogenic H-Ras protein into TGF $\beta$-arrested mink lung epithelial cells overcomes TGF $\beta$ growth inhibition and allows cell-cycle progression into S phase (Howe et al. 1993). Here, we describe a mechanism by which oncogenic Ras can induce such losses of TGF $\beta$ responsiveness.

Our results show that oncogenic Ras inhibits the TGFß signal transduction pathway at the level of Smad. As a readout of Smad transcriptional activity we used the A3-Luc reporter because activation of the enhancer element ARE that drives gene expression in A3-Luc depends on the direct binding of a TGF $\beta$-induced Smad (a TGF $\beta$-induced Smad complex) (Chen et al. 1997; Liu et al. 1997). Oncogenic Ras inhibits the A3-Luc transcriptional response to TGF $\beta$, both in mammary epithelial cells and lung epithelial cells. H-Ras ${ }^{\mathrm{V} 12}$ decreases the amplitude of the A3-Luc response by as much as $90 \%$. This is accompanied by a similar inhibition of the TGF $\beta$ antimitogenic response.

Ras signaling was shown previously to induce the phosphorylation of the BMP mediator Smad1 at four Erk consensus sites in the linker domain (Kretzschmar et al. 1997a). Phosphorylation of these four sites inhibits Smad1 accumulation in the nucleus without interfering with BMP-induced phosphorylation of Smad1. Many other serine residues present in the Smadl linker region 
A
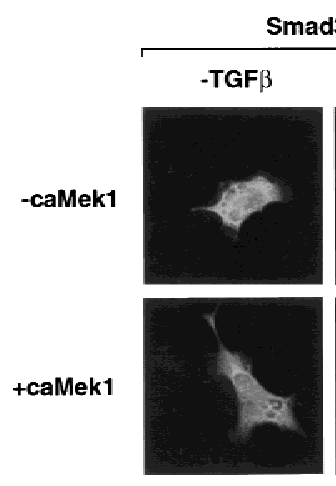

mad3 WT
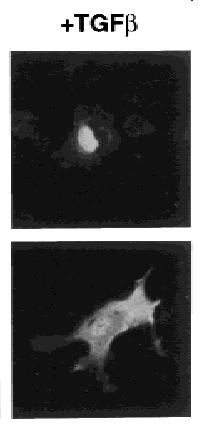

Smad3 EPSM

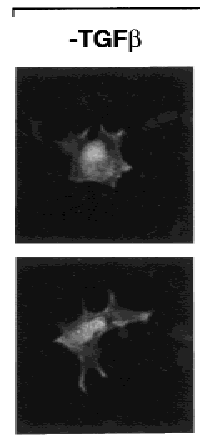

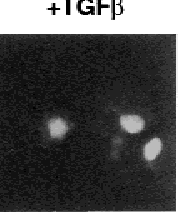

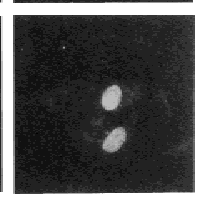

B

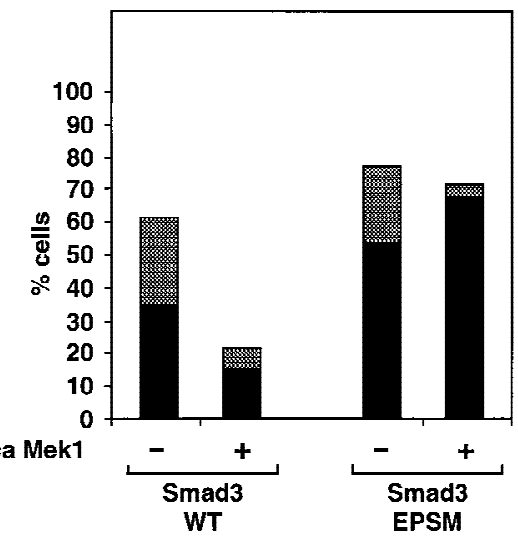

Figure 7. Mek1 inhibition of Smad3 nuclear accumulation requires phosphorylation in the linker domain. $(A) \mathrm{Mv} 1 \mathrm{Lu}$ cells were cotransfected with Flag-tagged Smad3 [wild-type (WT) or mutant (EPSM)] and empty vector or constitutively active Mek1 as indicated. TGF $\beta$ was added 30 min prior to fixation. Flag-Smad3 was visualized by anti-Flag immunofluorescence. $(B)$ Nuclear accumulation of Flag-Smad3 in the TGF $\beta$-treated cells of $A$ was quantitated by determining the proportion of cells with Smad2/Smad3 staining exclusively in the nucleus (e.g., as in $A$, far right; solid area) and cells with predominant but not exclusive nuclear staining (e.g., as in $A$, second from right; stippled area).

are not required for this effect (Kretzschmar et al. 1997a). A similar mechanism of regulation was not predicted for Smad2 or Smad3. These proteins are divergent from Smad1 in the linker region and have only one or two consensus Erk sites. However, our evidence suggests that clusters of four Ser/Thr-Pro sites including these Erk sites in the linker region of Smad2 and Smad3 are functionally equivalent to the four Erk sites of Smad1.

The following lines of evidence support the conclusion that Ras-induced phosphorylation of these sites prevents accumulation of Smad2 and Smad3 in the nucleus and inhibits TGF $\beta$ signaling. First, expression of oncogenic Ras elevates the phosphorylation of endogenous as well as exogenous Smad2 and Smad3. Second, Ras-induced phosphorylation of Smad2 and Smad3 is mimicked by expression of an activated Mek1 construct and is inhibited by addition of a specific Mek1 inhibitor. Third, these Ras- and Mek1-induced phosphorylations are prevented by mutation of the four Ser/Thr-Pro sites in the linker region of Smad2 and Smad3. These mutations also inhibit the phosphorylation of Smad2 and Smad3 by Erk2 in vitro. In contrast, mutation of the carboxy-terminal serines that serve as TGF $\beta$ receptor phosphorylation sites does not inhibit Ras-induced phosphorylation of Smad2 or Smad3. Fourth, expression of oncogenic Ras or constitutively active Mek1 inhibit the TGF $\beta$-induced accumulation of Smad2 and Smad3 in the nucleus. Fifth, Mek1 does not inhibit the TGF $\beta$-induced accumulation of a mutant Smad3 lacking the four Ras-dependent phosphorylation sites. Finally, expression of this Ras-resistant Smad3 mutant restores growth inhibitory and transcriptional responses to TGF $\beta$ in Ras-transformed cells.

\section{Smad2 and Smad3 integrate antagonistic TGF $\beta$ and Ras signals}

What is the role of this inhibitory mechanism in epithelial cells that contain a normal Ras pathway? We have approached this question by studying the effect of EGF, a physiological activator of this pathway (Vojtek and Der

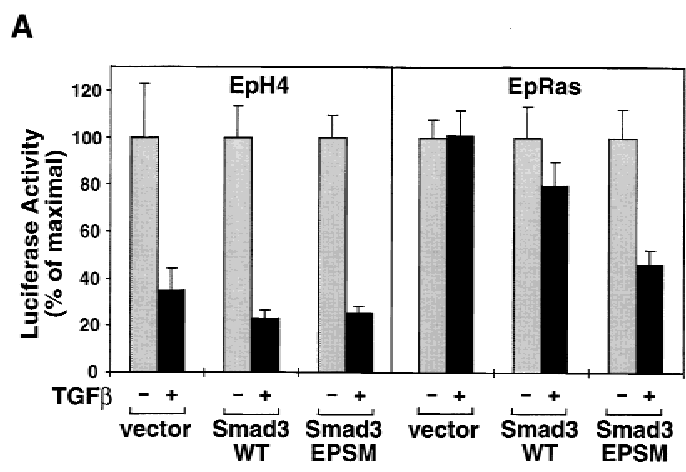

B

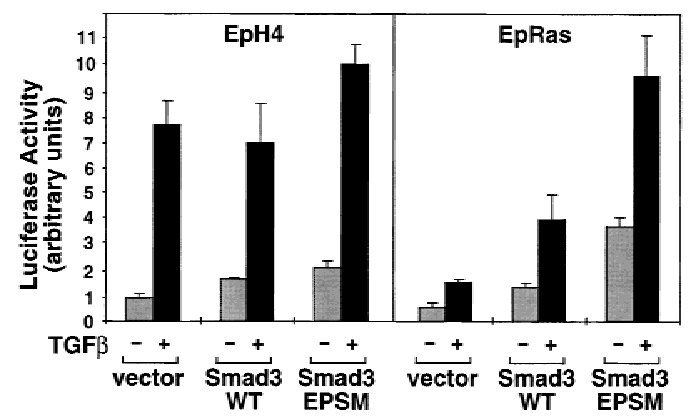

Figure 8. Ras-resistant Smad3 rescues TGF $\beta$ antimitogenic and transcriptional responses in EpRas cells. EpH4 and EpRas cells were cotransfected with wild-type Smad3, Ras-resistant (EPSM) Smad3 mutant, or the corresponding empty vector. These vectors were cotransfected with the E2F-luciferase reporter construct $(6 \times \mathrm{E} 2 \mathrm{~F}-\mathrm{Luc})$ in $A$, or the Smad-responsive ARE-luciferase reporter construct (A3-Luc) and FAST2 in $B$. Cells were incubated with or without TGF $\beta$ and luciferase activity was then measured. Data are the average of triplicates \pm S.D. 
1998). It should be noted that TGF $\beta$ is a potent inhibitor of the mitogenic response to EGF in MvlLu cells and other nontransformed epithelial cells (Like and Massagué 1986; Massagué 1990; Alexandrow and Moses 1995). TGF $\beta$ antagonizes these signals by inhibiting $G_{1}$ cyclin-dependent kinases (Koff et al. 1993; Hannon and Beach 1994; Polyak et al. 1994; Iavarone and Massagué 1997; Reynisdóttir and Massagué 1997). Therefore, EGF may not be expected to cause an extensive inhibition of TGF $\beta$ signaling, and our results agree with this. Like oncogenic Ras, EGF elevates the phosphorylation of Smad2 and Smad3, and this requires the four Ser/ThrPro sites in the linker region but not the carboxy-terminal receptor phosphorylation sites. However, EGF, which is weaker than oncogenic mutations at activating Ras, only tones down the nuclear accumulation of Smad 2 and Smad3. On balance, TGF $\beta$ prevails over EGF in the regulation of $\mathrm{Smad} 2 / \mathrm{Smad} 3$ nuclear accumulation. Thus, physiological signals and oncogenic mutations that activate Ras induce phosphorylation of the same inhibitory sites in Smad2 and Smad3, but with different intensities and different outcomes. Physiological activators such as EGF may use this mechanism to adjust the ability of Smad2 and Smad3 to convey TGF $\beta$ signals, whereas oncogenic Ras mutations may use it to disrupt TGF $\beta$ signaling.

Adjusting the ability of Smad2 and Smad3 to convey TGF $\beta$ signals may be important in processes that are cooperatively stimulated by TGF $\beta$ and Ras signals. Activin-like TGF $\beta$ family members cooperate with Ras signals in the induction of mesoderm in Xenopus (Whitman and Melton 1992). During endoderm formation in Drosophila, Ras signals and the TGF $\beta$ family member Dpp synergize in the induction of a common target gene, $U b x$, by activating separate sites in the $U b x$ promoter (Szüts et al. 1998). TGFß and EGF acting together allow the proliferation of fibroblasts under anchorage-deficient conditions (Roberts and Sporn 1990). TGF $\beta$ may allow the mitogenic stimulation of anchorage-deprived fibroblasts by inducing formation of extracellular matrix and cell adhesion to this matrix (Ignotz and Massagué 1986, 1987). Integrin-mediated adhesion to an extracellular matrix is required for effective mitogenic stimulation (Assoian and Zhu 1997).

EGF and hepatocyte growth factor (HGF) have been shown to activate the TGF $\beta$ reporter plasmid p3TP-Lux (Cárcamo et al. 1995; de Caestecker et al. 1998). On the basis of these and related observations, it has been proposed that EGF and HGF may signal through Smad2 (de Caestecker et al. 1998). Compared with TGF $\beta$, however, these factors induce minimal or no accumulation of Smad2 in the nucleus (de Caestecker et al. 1998; present results). It should be noted that the p3TP-Lux promoter contains three AP-1 sites (Cárcamo et al. 1995), and EGF can activate AP-1 directly through the Ras/MAPK pathway (Hunter and Karin 1992; Davis 1993). Other AP-1 activators such as phorbol esters also activate the 3TPLux construct (Cárcamo et al. 1995). Ras signaling slightly elevates the transcriptional activity of a GAL4Smad2 fusion construct (de Caestecker et al. 1998), but
Ras signaling has a general effect on transcription (Abdellatif et al. 1994) and can stimulate general transcriptional coactivators (Xu et al. 1998). Our results do not support the notion that EGF specifically signals through Smad2.

\section{Implications for cancer}

One physiological function of TGF $\beta$ is to constrain the proliferation of epithelial, endothelial, and hematopoietic cells, thus contributing to the maintenance of homeostasis in these tissues (Massagué 1990; Roberts and Sporn 1993; Alexandrow and Moses 1995). This function of TGF $\beta$ is often lost in cancer as a result of mutations that directly inactivate components of the growthinhibitory TGF $/$ Smad signaling pathway including T $\beta R-I I$, Smad2, and Smad4 (Markowitz et al. 1995; Eppert et al. 1996; Hahn et al. 1996; Heldin et al. 1997; T. Chen et al. 1998; Goggins et al. 1998; Massagué 1998; Grady et al. 1999|. However, many tumor cells without known mutations in these components are refractory to growth inhibition by TGF $\beta$. Understanding the mechanisms by which certain tumor cells selectively lose growth-inhibitory responses to TGF $\beta$ is therefore important for a better understanding of oncogenic processes.

We have investigated this problem in Ras-transformed mammary and lung epithelial cells. Our results suggest that hyperactive Ras can interfere with the TGF $/$ Smad signaling pathway by inhibiting nuclear accumulation of Smad2/Smad3. This mechanism may be operative in tumors that harbor a hyperactive Ras pathway. A substantial proportion of colon carcinomas and pancreatic carcinomas contain oncogenic Ras mutations (Fearon and Vogelstein 1990; Kern 1998), whereas breast carcinomas often contain HER2 and EGFR receptor tyrosine kinase amplifications (Clark and Der 1995). The colon carcinoma cell lines of known Ras status that we have screened to date show a correlation between the presence of oncogenic Ras mutations and a deficient nuclear accumulation of Smad2/Smad3. Tumors that contain inactivating mutations in T $\beta R I I, S m a d 2$, or Smad4 may suffer a more complete loss of TGF $\beta$ signaling than tumors containing Ras mutations. However, Ras mutations and mutations in TGF $\beta$ pathway components diminish TGF $\beta$ signaling with different outcomes. Ras transformation not only diminishes growth inhibition by TGF $\beta$, but it subverts this pathway into stimulating epithelial-mesenchymal transdifferentiation, invasion, and metastasis (Welch et al. 1990; Caulin et al. 1995; Oft et al. 1996, 1998; Sehgal et al. 1996; Farina et al. 1998; Yin et al. 1999). The inhibitory mechanism described here may allow the emergence of these tumorigenic responses through the residual activity of Smads remaining in the tumor cells or through as yet unknown Smadindependent pathways.

\section{Materials and methods}

Cell lines

Parental Mv1Lu cells were obtained from the American Type 
Culture Collection. Mv1Lu/R1B-L17 is a derivative cell line defective in the TGF $\beta$ type I receptor (T $\beta R I$ ) that has a high transfection efficiency and responds to TGF $\beta$ on transfection of T $\beta R-I$ (Wrana et al. 1994). EpH4 and EpRas were a generous gift of E. Reichmann (ISREC, Lausanne, Switzerland). Colon cancer cell lines were provided by N. Rosen (Memorial Sloan-Kettering Cancer Center, New York, NY).

\section{Transfections and metabolic labeling}

Most procedures were essentially carried out as described (Kretzschmar et al. 1997b). In brief, Mv1Lu/R1B-L17 mink lung epithelial cells were transiently transfected with Flag-tagged Smad2 or Smad3 constructs and H-Ras ${ }^{\mathrm{V} 12}$ or caMek1 vectors as indicated. Smad constructs and H-Ras ${ }^{\mathrm{V} 12}$ were in pCMV5 or pCS2, caMek1 was in pMCL. Mutant Smad constructs were obtained by standard in vitro mutagenesis procedures and were confirmed by sequencing. Three days post-transfection, cells were metabolically labeled for $3 \mathrm{hr}$ with ${ }^{32} \mathrm{P}$ and lysed. Where indicated, cells were treated with EGF ( $18 \mathrm{~nm}$; R\&D systems) for the indicated time, or with the Mek1 inhibitor PD98059 (100 $\mu M_{;}$New England Biolabs), or the PI3-kinase inhibitor wortmannin $(0.1 \mu \mathrm{M}$; Calbiochem) for $1.5 \mathrm{hr}$ prior to cell lysis. After cell lysis, Flag-Smad2 and Flag-Smad3 were precipitated with antiFlag antibody, resolved by SDS-PAGE, and visualized by autoradiography. Parallel cultures were treated equivalently, lysed, and subjected to Western immunoblotting with anti-Flag antibody and chemiluminescence (ECL, Amersham).

\section{Reporter assays}

Luciferase assays were essentially carried out as described (Kretzschmar et al. 1997a). The A3-Luc reporter construct was generated by subcloning the region comprising the three AREs and the core promoter from the previously described A3-CAT construct (Huang et al. 1995) into the pGL2-Basic luciferase vector (Promega). For A3-Luc assays, cells were transiently cotransfected with FAST-2 and A3-Luc vectors, serum-starved for $6 \mathrm{hr}$, treated with TGF $\beta$ at the indicated concentrations, and assayed for luciferase activity $18 \mathrm{hr}$ after factor addition. For E2F-luciferase assays, cells were transiently transfected with empty vector or vector encoding wild-type Smad3 or Smad3EPSM, as indicated, and the E2F-luciferase reporter construct 6×E2F-Luc (Lukas et al. 1997) as specified. Assays were carried out equivalently except that cells were not serum starved. EpH4 and EpRas cells were grown as described previously (Oft et al. 1996).

\section{Antibodies}

Anti-Smad2/Smad3 antibodies were raised in rabbits by immunization with the recombinant linker region of human Smad2 (amino acids 183-273), which is almost identical across species and highly homologous to the corresponding region in Smad3. These antibodies, referred to as anti-Smad2/Smad3, were affinity purified with immobilized Smad2 prior to use. Rabbit polyclonal antibodies raised against a peptide corresponding to amino acids 457-467 of Smad2, which included phosphorylated serine residues at positions 465 and 467 (Upstate Biotechnology, Lake Placid, NY) was used for Western immunoblotting of carboxyl terminus phosphorylated Smad2. Rabbit polyclonal antiErk antibodies used for Western immunoblotting (Upstate Biotechnology) and immunoprecipitation (Santa Cruz) recognize both Erk1 and Erk2. Monoclonal anti-Flag antibody (M2) was from Kodak Scientific.

\section{Immunofluorescence assays}

Vector, H-Ras ${ }^{\mathrm{V} 12}$, caMek1, GFP, or Flag-Smad3 constructs were transiently transfected $48 \mathrm{hr}$ prior to factor treatment. Cells were treated with TGF $\beta$ and/or EGF as specified and processed for immunofluorescence by a triple sandwich method (Harlow and Lane 1988). Endogenous Smad proteins were visualized with affinity-purified anti-Smad2/Smad3 antibodies, biotinconjugated anti-rabbit immunoglobulin and either FITC- or rhodamine-conjugated streptavidin (Jackson ImmunoResearch, West Grove, PA). Exogenous Flag-tagged Smad proteins were visualized with the triple sandwich method by use of M2 antiFlag monoclonal antibodies (Kodak) as primary antibodies. All slides were counterstained with DAPI to visualize cell nuclei (data not shown). In all cases, at least 100 stained cells were scored.

\section{Kinase assays}

Smad constructs were subcloned into a pET expression vector (Novagen) encoding an amino-terminal hexahistidine tag. Bacterial expression and purification of recombinant proteins were carried out as described (Kretzschmar et al. 1997b). Equivalent amounts of recombinant Smad3 proteins, as quantified by Coomassie staining and protein concentration assays, were incubated with recombinant, activated Erk2 MAP kinase (New England Biolabs) in the presence of $\left[\gamma^{32} \mathrm{P}\right] \mathrm{ATP}$ at $28-30^{\circ} \mathrm{C}$ for 20 min. Reactions were stopped by addition of SDS loading buffer and proteins resolved by SDS-PAGE.

\section{Phosphopeptide analysis}

EpRas cells were metabolically labeled for $3 \mathrm{hr}$ with ${ }^{32} \mathrm{P}$ and lysed. Endogenous Smad2/Smad3 was immunoprecipitated with affinity-purified anti-Smad2/Smad3 and separated by SDSPAGE. Endogenous Smad2/Smad3 was visualized by autoradiography and then electroeluted from the gel. The eluted protein was concentrated and aliquots incubated with trypsin or $\alpha$-chymotrypsin (both from Worthington, Lakewood, NJ). Resulting phosphopeptides were resolved by SDS-PAGE and visualized by autoradiography.

\section{Acknowledgments}

We thank E. Reichmann for kindly providing the EpH4 and EpRas cell lines, N. Rosen and L. Sepp-Lorenzino for tumor cell lines, E. Lai for the FAST2 vector, R. Derynck for the Smad3 vector, S. Mansour for the caMek1 vector, and A. Fattaey for the E2F-luciferase reporter. We also acknowledge the use of the Molecular Cytology Core Facility at Memorial Sloan-Kettering Cancer Center. This work was supported by Breast SPORE (Sppecialized Program of Research Excellence) and Cancer Center, National Institutes of Health grants to J.M. and to Memorial Sloan-Kettering Cancer Center. M.K. was a recipient of a postdoctoral fellowship from the Deutsche Forschungsgemeinschaft. J.M. is an Investigator of the Howard Hughes Medical Institute.

The publication costs of this article were defrayed in part by payment of page charges. This article must therefore be hereby marked 'advertisement' in accordance with 18 USC section 1734 solely to indicate this fact.

\section{References}

Abdellatif, M., W.R. MacLellan, and M.D. Schneider. 1994. p21Ras as a governor of global gene expression. J. Biol. Chem. 269: 15423-15426. 
Alessi, D.R., A. Cuenda, P. Cohen, D.T. Dudley, and A.R. Saltiel. 1995. PD 098059 is a specific inhibitor of the activation of mitogen-activated protein kinase kinase in vitro and in vivo. J. Biol. Chem. 270: 27489-27494.

Alexandrow, M.G. and H.L. Moses. 1995. Transforming growth factor $\beta$ and cell cycle regulation. Cancer Res. 55: 1452-1457.

Assoian, R.K. and X. Zhu. 1997. Cell anchorage and the cytoskeleton as partners in growth factor dependent cell cycle progression. Curr. Opin. Cell. Biol. 9: 93-98.

Barrack, E.R. 1997. TGF- $\beta$ in prostate cancer: A growth inhibitor that can enhance tumorigenicity. Prostate 31: 61-70.

Böttinger, E.P., V.M. Factor, M.L.S. Tsang, J.A. Weatherbee, J.B. Kopp, S.W. Qian, L.M. Wakefield, A.B. Roberts, S.S. Thorgeirsson, and M.B. Sporn. 1996. The recombinant proregion of transforming growth factor $\beta 1$ (latency-associated peptide) inhibits active transforming growth factor $\beta 1$ in transgenic mice. Proc. Nat1. Acad. Sci. 93: 5877-5882.

Cárcamo, J., A. Zentella, and J. Massagué. 1995. Disruption of TGF- $\beta$ signaling by a mutation that prevents transphosphorylation within the receptor complex. Mol. Cell. Biol. 15: 1573-1581.

Caulin, C., F.G. Scholl, P. Frontelo, C. Gamallo, and M. Quintanilla. 1995. Chronic exposure of cultured transformed mouse epidermal cells to transforming growth factor- $\beta 1$ induces an epithelial-mesenchymal transdifferentiation and a spindle tumoral phenotype. Cell Growth Differ. 6: 10271035.

Chen, T., D. Carter, L. Garrigue-Antar, and M. Reiss. 1998. Transforming growth factor $\beta$ type I receptor kinase mutant associated with metastatic breast cancer. Cancer Res. 58: 4805-4810.

Chen, X., E. Weisberg, V. Fridmacher, M. Watanabe, G. Naco, and M. Whitman. 1997. Smad4 and FAST-1 in the assembly of activin-responsive factor. Nature 389: 85-89.

Chen, Y., M.J. Rubock, and M. Whitman. 1996. A transcriptional partner of MAD proteins in TGF- $\beta$ signalling. Nature 383: 691-696.

Chen, Y.G., A. Hata, R.S. Lo, D. Wotton, Y. Shi, N. Pavletich, and J. Massagué. 1998. Determinants of specificity in TGF- $\beta$ signal transduction. Genes \& Dev. 12: 2144-2152.

Clark, G.J. and C.J. Der. 1995. Aberrant function of the Ras signal transduction pathway in human breast cancer. Breast Cancer Res. Treat. 35: 133-144.

Cui, W., D.J. Fowlis, S. Bryson, E. Duffie, H. Ireland, A. Balmain, and R.J. Akhurst. 1996. TGF $\beta 1$ inhibits the formation of benign skin tumors, but enhances progression to invasive spindle carcinomas in transgenic mice. Cell 86: 531-542.

Davis, R.J. 1993. The mitogen-activated protein kinase signal transduction pathway. J. Biol. Chem. 268: 14553-14556.

de Caestecker, M.P., W.T. Parks, C.J. Frank, P. Castagnino, D.P. Bottaro, A.B. Roberts, and R.J. Lechleider. 1998. Smad2 transduces common signals from receptor serine-threonine and tyrosine kinases. Genes \& Dev. 12: 1587-1593.

Derynck, R., J.A. Jarrett, E.Y. Chen, D.H. Eaton, J.R. Bell, R.K. Assoian, A.B. Roberts, M.B. Sporn, and D.V. Goeddel. 1985. Human transforming growth factor- $\beta$ complementary DNA sequence and expression in normal and transformed cells. Nature 316: 701-705.

Eppert, K., S.W. Scherer, H. Ozcelik, R. Pirone, P. Hoodless, H. Kim, L.-C. Tsui, B. Bapat, S. Gallinger, I.L. Andrulis, G.H. Thomsen, J.L. Wrana, and L. Attisano. 1996. MADR2 maps to $18 \mathrm{q} 21$ and encodes a TGF $\beta$-regulated MAD-related protein that is functionally mutated in colorectal carcinoma. Cell 86: 543-552.

Factor, V.M., C.-Y. Cao, E. Santoni-Rugiu, J.T. Woitach, M.R.
Jensen, and S.S. Thorgeison. 1997. Constitutive expression of mature transforming growth factor $\beta 1$ in the liver accelerates hepatocarcinogenesis in transgenic mice. Cancer Res. 57: 2089-2095.

Farina, A.R., A. Coppa, A. Tiberio, A. Tacconelli, A. Turco, G. Colletta, A. Gulino, and A.R. Mackay. 1998. Transforming growth factor- $\beta 1$ enhances the invasiveness of human MDAMB-231 breast cancer cells by up-regulating urokinase activity. Int. J. Cancer 75: 721-730.

Fearon, E.R. and B. Vogelstein. 1990. A genetic model for colorectal tumorigenesis. Cell 61: 759-767.

Filmus, J. and R.S. Kerbel. 1993. Development of resistance mechanisms to growth-inhibitory effects of transforming growth factor- $\beta$ during tumor progression. Curr. Opin. Oncol. 5: 123-129.

Goggins, M., M. Shekher, K. Turnacioglu, C.J. Yeo, R.H. Hruban, and S.E. Kern. 1998. Genetic alterations of the transforming growth factor $\beta$ receptor genes in pancreatic and biliary adenocarcinomas. Cancer Res. 58: 5329-5332.

Gorska, A.E., H. Joseph, R. Derynck, H.L. Moses, and R. Serra. 1998. Dominant-negative interference of the transforming growth factor $\beta$ type II receptor in mammary gland epithelium results in alveolar hyperplasia and differentiation in virgin mice. Cell Growth Differ. 9: 229-238.

Grady, W.M., L.L. Myeroff, S.E. Swinler, A. Rajput, S. Thiagalingam, J.D. Lutterbaugh, A. Neumann, J. Chang, S.-J., Kim, K.W. Kinzler, B. Vogelstein, J.K.V. Willson, and S. Markowitz. 1999. Mutational inactivation of transforming growth factor $\beta$ receptor type II in microsatelite stable colon cancers. Cancer Res. 59: 320-324.

Hahn, S.A., M. Schutte, A.T.M.S. Hoque, C.A. Moskaluk, L.T. da Costa, E. Rozenblum, C.L. Weinstein, A. Fischer, C.J. Yeo, R.H. Hruban, and S.E. Kern. 1996. DPC4, a candidate tumor suppressor gene at human chromosome 18q21.1. Science 271: 350-353.

Hannon, G.J. and D. Beach. 1994. p15INK4B is a potential effector of TGF- $\beta$-induced cell cycle arrest. Nature 371: 257 261.

Harlow, E. and D. Lane. 1988. Antibodies: A laboratory handbook. Cold Spring Harbor Laboratory Press, Cold Spring Harbor, NY.

Heldin, C.-H., K. Miyazono, and P. ten Dijke. 1997. TGF- $\beta$ signalling from cell membrane to nucleus through SMAD proteins. Nature 390: 465-471.

Houck, K.A., G.K. Michalopoulos, and S.C. Strom. 1989. Introduction of a Ha-ras oncogene into rat liver epithelial cells and parenchymal hepatocytes confers resisitance to the growth inhibitory effects of TGF- $\beta$. Oncogene 4: 19-25.

Howe, P.H., S.F. Dobrowolski, K.B. Reddy, and D.W. Stacey. 1993. Release from $\mathrm{G} 1$ growth arrest by transforming growth factor $\beta 1$ requires ras activity. I. Biol. Chem. 268: 2144821452.

Huang, H.-C., L.C. Murtaugh, P.D. Vize, and M. Whitman. 1995. Identification of a potential regulator of early transcriptional responses to mesoderm inducers in the frog embryo. EMBO J. 14: 5965-5973.

Hunter, T. and M. Karin. 1992. The regulation of transcription by phosphorylation. Cell 70: 375-387.

Iavarone, A. and J. Massagué. 1997. Repression of the CDK activator Cdc25A and cell-cycle arrest by cytokine TGF- $\beta$ in cells lacking the CDK inhibitor p15. Nature 387: 417-422.

Ignotz, R.A. and J. Massagué. 1986. Transforming growth factor- $\beta$ stimulates the expression of fibronectin and collagen and their incorporation into the extracellular matrix. J. Biol. Chem. 261: 4337-4345.

- 1987. Cell adhesion protein receptors as targets for 
transforming growth factor- $\beta$. Cell 51: 189-197.

Kern, S.E. 1998. Advances from genetic clues in pancreatic cancer. Curr. Opin. Oncol. 10: 74-80.

Keski-Oja, J., E.B. Leof, R.M. Lyons, R.J.J. Coffey, and H.L. Moses. 1987. Transforming growth factors and control of neoplastic cell growth. J. Cell. Biochem. 33: 95-107.

Koff, A., M. Ohtsuki, K. Polyak, J.M. Roberts, and J. Massagué. 1993. Negative regulation of G1 in mammalian cells: Inhibition of cyclin E-dependent kinase by TGF- $\beta$. Science 260: 536-539.

Kretzschmar, M., J. Doody, and J. Massagué. 1997a. Opposing BMP and EGF signalling pathways converge on the TGF $\beta$ family mediator Smad1. Nature 389: 618-622.

Kretzschmar, M., F. Liu, A. Hata, J. Doody, and J. Massagué. 1997b. The TGF- $\beta$ mediator Smadl is directly phosphorylated and functionally activated by the BMP receptor kinase. Genes \& Dev. 11: 984-995.

Labbé, E., C. Silvestri, P.A. Hoodless, J.L. Wrana, and L. Attisano. 1998. Smad2 and Smad3 positively and negatively regulate TGF $\beta$-dependent transcription through the forkhead DNA-binding protein FAST2. Mol. Cell 2: 109-120.

Letterio, J.L. and A.B. Roberts. 1998. Regulation of immune responses by TGF- $\beta$. Annu. Rev. Immunol. 16: 137-161.

Like, B. and J. Massagué. 1986. The antiproliferative effect of type $\beta$ transforming growth factor occurs at a level distal from receptors for growth-activating factors. J. Biol. Chem. 261: 13426-13429.

Liu, B., C. Dou, L. Prabhu, and E. Lai. 1999. Fast2 is a mammalian winged helix protein that mediates TGF $\beta$ signals. Mol. Cell. Biol. 19: 424-430.

Liu, F., C. Pouponnot, and J. Massagué. 1997. Dual role of the Smad4/DPC4 tumor suppressor in TGF 3 -inducible transcriptional responses. Genes \& Dev. 11: 3157-3167.

Longstreet, M., B. Miller, and P.H. Howe. 1992. Loss of transforming growth factor $\beta 1$ (TGF- $\beta 1$ )-induced growth arrest and $\mathrm{p} 34 \mathrm{cdc} 2$ regulation in ras-transfected epithelial cells. Oncogene 7: 1549-1556.

Lukas, J., T. Herzinger, K. Hansen, M.C. Moroni, D. Resnitzky, K. Helin, S.I. Reed, and J. Bartek. 1997. Cyclin E-induced S phase without activation of the pRb/E2F pathway. Genes \& Dev. 11: 1479-1492.

Macias-Silva, M., S. Abdollah, P.A. Hoodless, R. Pirone, L. Attisano, and J.L. Wrana. 1996. MADR2 is a substrate of the TGF $\beta$ receptor and phosphorylation is required for nuclear accumulation and signaling. Cell 87: 1215-1224.

Markowitz, S., J. Wang, L. Myeroff, R. Parsons, L. Sun, J. Lutterbaugh, R.S. Fan, E. Zborowska, K.W. Kinzler, B. Vogelstein, M. Brattain, and J.K.V. Wilson. 1995. Inactivation of the type II TGF- $\beta$ receptor in colon cancer cells with microsatellite instability. Science 268: 1336-1338.

Massagué, J. 1990. The transforming growth factor- $\beta$ family. Annu. Rev. Cell. Biol. 6: 597-641.

- 1998. TGFß signal transduction. Annu. Rev. Biochem. 67: 753-791.

Oft, M., J. Peli, C. Rudaz, H. Schwarz, H. Beug, and E. Reichmann. 1996. TGF- $\beta 1$ and Ha-Ras collaborate in modulating the phenotypic plasticity and invasiveness of epithelial tumor cells. Genes \& Dev. 10: 2462-2477.

Oft, M., K.H. Heider, and H. Burg. 1998. TGF- $\beta$ signaling is necessary for carcinoma cell invasiveness and metastasis. Curr. Biol. 8: 1243-1252.

Polyak, K., M.-H. Lee, H. Erdjument-Bromage, A. Koff, J.M. Roberts, P. Tempst, and J. Massagué. 1994. Cloning of p27 kip1, a cyclin-dependent kinase inhibitor and a potential mediator of extracellular antimitogenic signals. Cell 78: 59-66.

Reiss, M. and M.H. Barcellos-Hoff. 1997. Transforming growth factor- $\beta$ in breast cancer: A working hypothesis. Breast Cancer Res. Treat. 45: 81-95.

Reynisdóttir, I. and J. Massagué. 1997. The subcellular location of $\mathrm{p} 15^{\text {Ink4b }}$ and $\mathrm{p} 27^{\text {Kip1 }}$ coordinate their inhibitory interactions with cdk4 and cdk2. Genes \& Dev. 11: 492-503.

Roberts, A.B. and M.B. Sporn. 1990. The transforming growth factor-betas. In Peptide growth factors and their receptors (ed. M.B. Sporn and A.B. Roberts), pp. 419-472, SpringerVerlag, Heidelberg, Germany.

- 1993. Physiological actions and clinical applications of transforming growth factor- $\beta$ (TGF- $\beta$ ). Growth Factors 8: 1-9.

Schwarz, L.C., M.C. Gingras, G. Goldberg, A.H. Greenberg, and J.A. Wright. 1988. Loss of growth factor dependence and conversion of transforming growth factor- $\beta 1$ inhibition to stimulation in metastatic H-ras-transformed murine fibroblasts. Cancer Res. 48: 6999-7003.

Sehgal, I., P.A. Baley, and T.C. Thompson. 1996. Transforming growth factor $\beta 1$ stimulates contrasting responses in metastatic versus primary mouse prostate cancer-derived cell lines in vitro. Cancer Res. 56: 3359-3365.

Sepp-Lorenzino, L., Z. Ma, E. Rands, N.E. Kohl, J.B. Gibbs, A. Oliff, and N. Rosen. 1995. A peptidomimetic inhibitor of farnesyl:protein transferase blocks the anchorage-dependent and -independent growth of human tumor cell lines. Cancer Res. 55: 5302-5309.

Shi, Y., A. Hata, R.S. Lo, J. Massagué, and N.P. Pavletich. 1997. A structural basis for the mutational inactivation of the Smad4 tumour suppressor. Nature 388: 87-93.

Shi, Y., Y.-F. Wang, L. Jayaraman, H. Yang, J. Massagué, and N. Pavletich. 1998. Crystal structure of Smad MH1 domain bound to DNA: Insights on DNA-binding and TGFß signaling. Cell 94: 585-594.

Szüts, D., S. Eresh, and M. Bienz. 1998. Functional intertwining of Dpp and EGFR signaling during Drosophila endoderm induction. Genes \& Dev. 12: 2022-2035.

Takaku, K., M. Oshima, H. Miyoshi, M. Matsui, M.F. Seldin, and M.M. Taketo. 1998. Instestinal tumorigenesis in compound mutant mice of both $\mathrm{Dpc} 4$ (Smad4) and APC genes. Cell 92: 645-656.

Ui, M., T. Okada, K. Hazeki, and O. Hazeki. 1995. Wortmannin as a unique probe for an intracellular signalling protein, phosphoinositide 3-kinase. Trends Biochem. Sci. 20: 303-307.

Valverius, E.M., D. Walker-Jones, S.E. Bates, M.R. Stampfer, R. Clark, F. McCormick, R.B. Dickson, and M.E. Lippman. 1989. Production and responsiveness to transforming growth factor- $\beta$ in normal and oncogene-transformed human mammary epithelial cells. Cancer Res. 49: 6269-6274.

Vojtek, A.B. and C.J. Der. 1998. Increasing complexity of the Ras signaling pathway. J. Biol. Chem. 273: 19925-19928.

Wang, X.J., D.A. Greenhalgh, J.R. Bickenbach, A. Jiang, D.S. Bundman, T. Krieg, R. Derynck, and D.R. Roop. 1997. Expression of a dominant-negative type II transforming growth factor $\beta$ (TGF- $\beta$ ) receptor in the epidermis of transgenic mice blocks TGF- $\beta$-mediated growth inhibition. Proc. Nat1. Acad. Sci. 94: 2386-2391.

Welch, D.R., A. Fabra, and M. Nakajima. 1990. Transforming growth factor $\beta$ stimulates mammary adenocarcinoma cell invasion and metastatic potential. Proc. Natl. Acad. Sci. 87: 7678-7682.

Whitman, M. and D.A. Melton. 1992. Involvement of p21ras in Xenopus mesoderm induction. Nature 357: 252-254.

Wrana, J.L., L. Attisano, R. Wieser, F. Ventura, and J. Massagué. 1994. Mechanism of activation of the TGF- $\beta$ receptor. $\mathrm{Na}$ ture 370: 341-347. 
Kretzschmar et al.

Xu, L., R.M. Lavinsky, J.S. Dasen, S.E. Flynn, E.M. McInerney, T.-M. Mullen, T. Heinzel, D. Szeto, E. Korzus, R. Kurokawa, A.K. Aggarwal, D.W. Rose, C.K. Glass, and M.G. Rosenfeld. 1998. Signal-specific co-activator domain requirements for Pit-1 activation. Nature 395: 301-306.

Yin, J.J., K. Selander, J.M. Chirwing, M. Dallas, B.G. Grubbs, R. Wieser, J. Massagué, G.R. Mundy, and T.A. Guise. 1999. Blockade of transforming growth factor $\beta$ signaling inhibits parathyroid hormone-related protein secretion by breast cancer cells and the development of bone metastases. J. Clin. Invest. 103: 197-206.

Zhang, Y., X.-H. Feng, R.-Y. Wu, and R. Derynck. 1996. Receptor-associated Mad homologs synergize as effectors of the TGF $\beta$ response. Nature 383: 168-172.

Zhou, S., L. Zawel, C. Lengauer, K.W. Kinzler, and B. Vogelstein. 1998. Characterization of human FAST-1, a TGF $\beta$ and activin signal transducer. Mol. Cell 2: 121-127.

Zhu, Y., J.A. Richardson, L.F. Parada, and J.M. Graff. 1998. Smad3 mutant mice develop metastatic colorectal carcinoma. Cell 94: 703-714. 


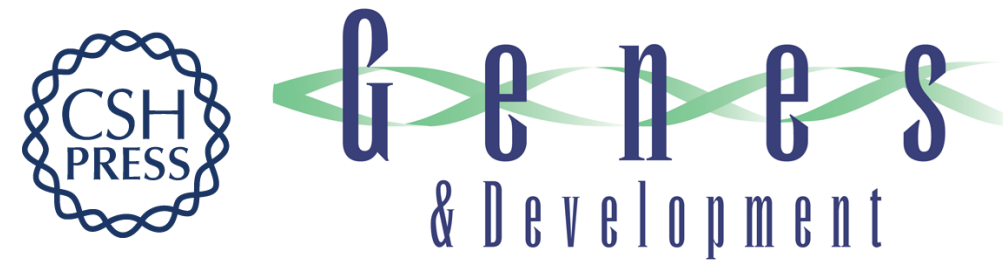

\section{A mechanism of repression of TGF $\beta$ / Smad signaling by oncogenic Ras}

Marcus Kretzschmar, Jacqueline Doody, Inna Timokhina, et al.

Genes Dev. 1999, 13:

References This article cites 76 articles, 34 of which can be accessed free at: http://genesdev.cshlp.org/content/13/7/804.full.html\#ref-list-1

License

Email Alerting

Service

Receive free email alerts when new articles cite this article - sign up in the box at the top right corner of the article or click here.

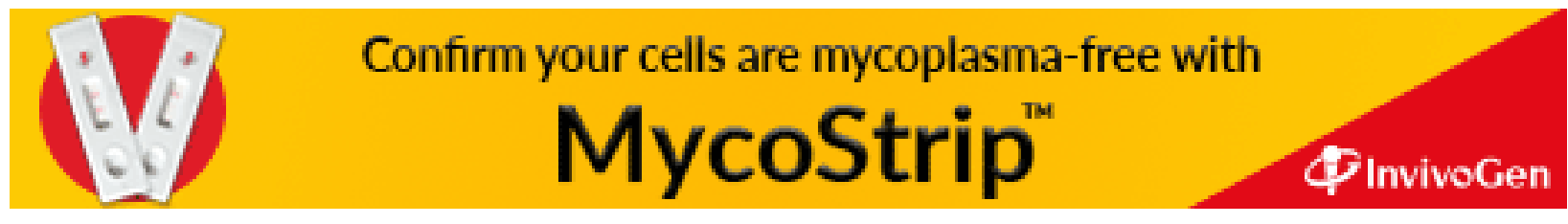

